\title{
Evaluation of the Effect of Thermo-mechanical Treatment on the Resistance of Commercial OSB to Decay Fungi
}

\author{
Matheus Couto CRISÓSTOMO*, Claudio Henrique Soares DEL MENEZZI
}

\author{
Department of Forest Engineering, Faculty of Technology, University of Brasília, 70904-970, Brasília, DF, Brazil \\ crossref http://dx.doi.org/10.5755/j01.ms.25.2.19547
}

Received 23 November 2017; accepted 04 April 2018

\begin{abstract}
The chemical treatment of wood has been widely used in combating rot fungi. However, it's a process that involves the insertion of chemical agents, which are subject to leaching when exposed to weathering. In this context, the thermomechanical modification seeks to increase the durability of wood, without polluting the environment. Samples of untreated and thermo-mechanically treated Oriented Strand Board (OSB) were exposed to the attack of rotting fungi. Both untreated and treated samples were classified as resistant to the attack of $T$. versicolor (white-rot). To the attack of G.trabeum (brown-rot), the untreated samples were classified as moderate resistance, and the treated samples as resistant. The results of mass loss showed that the thermo-mechanical treatment caused an increase of $19.34 \%$ (whiterot) and $43.03 \%$ (brown-rot) in the OSB resistance, and also improved the OSB resistance class from moderately resistant to resistant to brown-rot fungi.

Keywords: oriented strand board, thermo-mechanical treatment, rotting fungi.
\end{abstract}

\section{INTRODUCTION}

Wood is a renewable material that presents wide transformation versatility to reach the highest standards of use. However, the strong pressure over the forest resources, and the environmental consciousness of society, provoked an increase in the cost of this material, so the search for more efficient use led to the development of new products, including the Oriented Strand Board (OSB) panel, a reconstituted product characterized by its long rectangular-shaped particles, oriented in the same direction and consolidated by thermo-compression.

To reach the standards for structural use, the OSB panel must show little variation of its properties, specially the dimensional stability and the natural resistance to microorganisms and xylophagous bugs, even when exposed to weather conditions, like such as outdoor use.In this context, Hill [1] states that the thermo-mechanical modification of wood can be considered a technique that improves the wood and derivatives properties, delivering a product that will not become a risk to the environment at the end of lifespan since this technique involves the exposure of wood to heat and mechanical compression effort, without the insertion of chemicals.

When wood is heated under controlled conditions of temperature, time and humidity, it may become subject to permanent changes, becoming less hygroscopic, more hydrophobic and more resistant to biological attack [2-3], behavior that is justified by the thermal degradation of wood chemical components and also by the change of their chemical structures, in addition to changes in the morphology of the anatomical components [4].

In addition, the equilibrium moisture of wood and the availability of hemicelluloses are altered, and new fungicidal molecules are produced, affecting the substrate

${ }^{*}$ Corresponding author. Tel.: +55-61-35541293.

E-mail address: matheuscc50@hotmail.com (M.C. Crisóstomo) identification's mechanism of fungi [5], which leads to an increase in the biological resistance of wood.

In order to evaluate the resistance of wood to attack of microorganisms, accelerated decay laboratory tests were developed, allowing the material to have contact with rotting fungi, microorganisms that have the ability to modify the cell anatomic structure and therefore, the physical, chemical and mechanical properties of wood [6]. The natural resistance is classified according to the residual mass after the exposure period. The main used fungi for accelerated decay tests are brown-rot (Gloeophyllumtrabeum), and white-rot (Trametesversicolor), whose choice is justified because these fungi have different degradation mechanisms, with the brown-rot fungus primarily attacks cellulose and hemicellulose, while white-rot fungus attack all the wood components [7].

Thus, the objective of this work was to evaluate the resistance of OSB samples, untreated and thermomechanically treated to the brown and white rotting fungi.

\section{MATERIAL AND METHODS}

\subsection{Wood Panel}

For the study, and OSB panel was acquired in the timber market of Distrito Federal (DF), made from Pinus sp., three-layer composition, commercial dimensions of 244 by 122 by $1.5 \mathrm{~cm}$ (length $\mathrm{x}$ width $\mathrm{x}$ thickness), and $0.59 \mathrm{~g} / \mathrm{cm}^{3}$ of nominal density.

The experimental design consisted of two treatments, being them original condition (untreated) and thermomechanically treated (densified). Two samples (one per treatment) with the dimensions of 40 by 40 by $1.5 \mathrm{~cm}$ (length $\mathrm{x}$ width $\mathrm{x}$ thickness) were cut from the acquired OSB panel. 


\subsection{Thermo-mechanicaltreatment}

The application of thermo-mechanical treatment (densification) was carried out using a hydraulic press. The treatment applied was developed by [8], and proceeded in three steps:

- heating: initial temperature to $190^{\circ} \mathrm{C}$ and full pressure (1.5 MPa);

- treatment: $190^{\circ} \mathrm{C}$ and (1.5 MPa) over a period of 10 minutes;

-post-treatment: $190{ }^{\circ} \mathrm{C}$ and half pressure release $(0.75 \mathrm{MPa})$ over a period of 5 minutes, and $190{ }^{\circ} \mathrm{C}$ withall the pressure released over a period of 5 minutes.

\subsection{Test blocks}

The test to assess the attack of brown and white-rot fungi on untreated and thermo-mechanically treated OSB was carried out in the Biodegradation and Preservation Area, of the Forest Products Laboratory (LPF)/ Brazilian Forest Service in Brasília (DF) in according to the Standards tests [9].

The samples were sawn into test blocks (Fig. 1) measuring 2.5 by $2.5 \mathrm{~cm}$ (length $\mathrm{x}$ width) by treatmentthickness for each treatment (untreated and densified), totaling 60 samples by fungus tested.

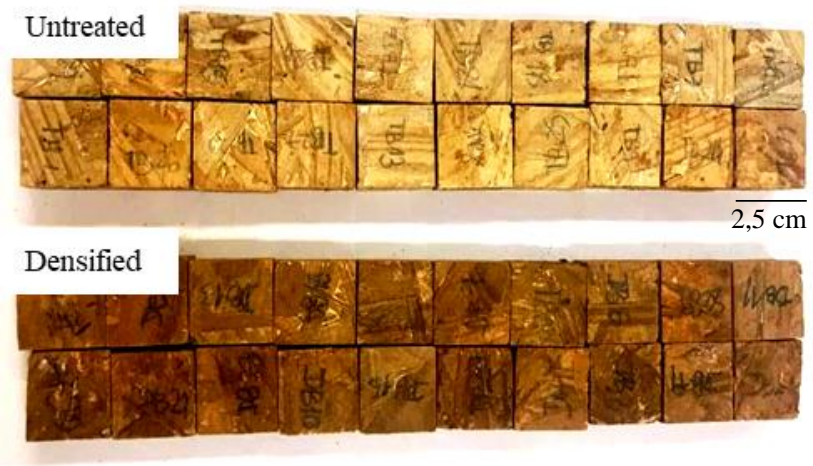

Fig. 1. Test blocks of untreated and thermo-mechanically treated (Densified) OSB

Subsequently, the test blocks were conditioned in an oven with forced air circulation, at $50{ }^{\circ} \mathrm{C}$ until reaching constant weight. Then, the initial oven-dry weight (Wi) of each test block was determinate in a digital scale with $0.0001 \mathrm{~g}$ precision.

\subsection{Control Samples}

Boards of Cecropia spp. and Pinus sp. were sawn into 32 control samples (half for each species) measuring 2.5 by 2.5 by $0.9 \mathrm{~cm}$ (length $\times$ width $\times$ thickness).

The control samples are used as indicators of the vegetative vigor of the inoculated fungal culture and of the incubation conditions, so, according to [9], the test is scientifically valid only if the fungus causes a weight loss of at least $50 \%$ on the control samples after 16 weeks.

\subsection{Accelerated laboratory tests of decay resistance of wood}

The soil-block test for each fungi were prepared in $100 \mathrm{~mL}$ cylindrical culture bottles using $50 \mathrm{~g}$ of red latosol, $45 \mathrm{~mL}$ of distilled water, and a feeder strip of Crecropia spp. with dimensions of 3.5 by 2.9 by $0.3 \mathrm{~cm}$ (length $\times$ width $\times$ thickness).

Thereafter, the bottles were sterilized at $121{ }^{\circ} \mathrm{C}$ on a $1 \mathrm{~atm}$ pressure, for 45 minutes, and placed in incubation chamber at $26^{\circ} \mathrm{C}$ and $70 \%$ of moisture over a period of 30 days, to observe evidence of contamination.

The culture bottles were then inoculated with brownrot fungus Gloeophyllumtrabeum(Persoon. Ex Fries.) and with white-rot fungus Trametes versicolor (Linnaeus ex Fries), both collected from mycology collection of the LPF, and applied over the feeder strip for 30 days.

After the fungus growth period, the test blocks were placed over the feeder strips, and the culture bottles were placed in the incubator chamber for eight weeks.

At the ninth week, two control samples per fungi were removed from the culture bottles and any surface fungus growth was carefully brushed off. Then the samples were placed in oven and dried at $50{ }^{\circ} \mathrm{C}$ once again until constant weight was reached to obtain the final oven-dry weight (Wf). When the weight losses in the control samples reached $50 \%$ or more, the tests were finished, and the test blocks were removed from the culture bottles to pass through cleaning process, removing the fungi that had growth over the surface. Subsequently, the test blocks were placed in an oven at $50{ }^{\circ} \mathrm{C}$ until reaching a constant mass and had their final weight $(W f)$.

The OSB susceptibility to fungi attack was evaluated throughout the percentage of weight loss $(W L)$, before and after exposure to decay, given by Eq. 1 .

$W L(\%)=\{(W \mathrm{i}-W \mathrm{f}) / W \mathrm{i}\} \times 100$,

where $W L$ is the weight loss in \%; Wi is the initial weight in $\mathrm{g}$; $W f$ is the final weight in $\mathrm{g}$.

Then, untreated and thermo-mechanically treated (densified) OSB had their resistance classified according to Table 1 criteria.

Table 1. Classes of resistance to decay fungi

\begin{tabular}{|c|c|}
\hline Class of resistance & Weight loss, \% \\
\hline Highly Resistant - HR & $0-10$ \\
\hline Resistant - R & $11-24$ \\
\hline Moderately Resistant - MR & $25-44$ \\
\hline Not Resistant- NR & $45<$ \\
\hline
\end{tabular}

\subsection{Data analysis}

The data were analyzed using SPSS (Statistical Package for Social Sciences) software version 21.0.

The class of resistance was determined through descriptive analysis, considering the mean values of initial weight, final weight, and weight loss of the OSB samples without treatment (untreated) and with thermo-mechanical treatment (densified).

A statistical analysis based on a one-way analysis of variance (ANOVA) was performed to identify the effectiveness of thermo-mechanical treatment, and for thetype of fungus, both at 5\% level of significance $(\mathrm{p}=0.05)$.

\section{RESULTS AND DISCUSSION}

The control samples of Pinus sp. reached weight loss above $50 \%$ in the ninth week, while Cecropia spp. 
reached weight loss above $50 \%$ only in the fourteenth week, proving that the inoculated fungi presented satisfactory vigor, and therefore the test is scientifically valid according to the criteria established byASTM D2007 [9].

The test data of the attack of white-rot and brown-rot fungi on untreated and thermo-mechanically treated OSB samples are summarized in Table 2. The data presented is the mean value of the Initial weight $(W i)$, the final weight $(W f)$ and the weight loss (WL) for the 30 samples prepared for each treatment (untreated and densified) and fungi (brown and white-rot) as well as the reduction (or increase) by type of treatment or fungi.

Table 2. Attack of white-rot and brown-rot fungi on untreated and thermo-mechanically treated OSB samples

\begin{tabular}{|c|c|c|c|c|}
\hline \multirow{3}{*}{ Treatment } & \multicolumn{4}{|c|}{ Weight, $g$} \\
\hline & \multicolumn{2}{|c|}{$\mathrm{Wi}$} & \multicolumn{2}{|c|}{ Wf } \\
\hline & $\begin{array}{l}\text { brown- } \\
\text { rot }\end{array}$ & $\begin{array}{c}\text { white- } \\
\text { rot }\end{array}$ & $\begin{array}{l}\text { brown- } \\
\text { rot }\end{array}$ & $\begin{array}{l}\text { white- } \\
\text { rot }\end{array}$ \\
\hline Untreated & $5.20 *$ & $5.13 *$ & $3.20 *$ & $4.18 *$ \\
\hline Densified & $5.59 *$ & $5.55 *$ & $4.36^{*}$ & $4.72 *$ \\
\hline \multirow[b]{2}{*}{ Treatment } & \multicolumn{4}{|c|}{ Weight loss, $\%$} \\
\hline & $\begin{array}{l}\text { brown- } \\
\text { rot }\end{array}$ & $\begin{array}{c}\text { white- } \\
\text { rot }\end{array}$ & \multicolumn{2}{|c|}{$\begin{array}{c}\text { Reduction or (increase) } \\
\text { by type of fungus, } \%\end{array}$} \\
\hline Untreated & $38.51^{*}$ & $18.41^{*}$ & \multicolumn{2}{|c|}{109.18} \\
\hline Densified & $21.94 *$ & $14.85^{*}$ & \multicolumn{2}{|c|}{47.74} \\
\hline $\begin{array}{l}\text { Reduction by } \\
\text { treatment, \% }\end{array}$ & 43.03 & 19.34 & \multicolumn{2}{|c|}{ - } \\
\hline
\end{tabular}

As shown in Table 2, untreated OSB samples exposed to G.trabeum and T.versicolor were being susceptible to brown and white-rot, causing a weight loss of $38.51 \%$ and $18.41 \%$, confirming that even the presence of free phenolic and formaldehyde from the adhesive could not avoid the samples's decay. Bravery and Lea's studyaffirmsthat the adhesive residue is susceptible to leaching and volatilization, so it cannot provide lasting protection [10].

There was an increase in the weight loss of the OSB samples due to the type of fungus used, which demonstrates that the OSB panel is more susceptible to the attack of G.trabeum(brown-rot), compared to the attack of T. versicolor (white-rot). This behavior was already expected because the tested OSB panel was made with Pinus sp. wood, and according toMartinez et al. [11], brown-rot fungi grow mainly on soft-woods (gymnosperms), different from the white-rot fungi which grow mainly on hardwoods (angiosperms).

Dutton et al. [12] states that these variations are explained because the brown-rot fungus secrete large amounts of oxalate, which reduces the $\mathrm{pH}$ of the substrate, different from the white-rot fungi mechanism of degradation, which does not secrete oxalate enough to alter the $\mathrm{pH}$ of the medium.Consequently, Goodell et al. [13] states that the oxalic acid $\left(\mathrm{H}_{2} \mathrm{C}_{2} \mathrm{O}_{2}\right)$ reacts with the ions present in the wood, process known as Fenton reaction, resulting in hydroxyl radicals that cause the cleavage of the long chains of cellulose, which leads to the increase of porosity of the cell wall, and therefore to the insertion of degradative enzymes. These enzymes act causing the depolymerization of polysaccharides, provoking serious consequences in the mechanical properties of wood [14].

After the same period, the thermo-mechanically treated OSB panel presented higher resistance to both fungi, losing $21.94 \%$ and $14.85 \%$ of their initial weight after the attack of brown-rot and white-rot fungi, respectively.

According to Weiland \&Guyonnet [5], the higher resistance after the exposure of wood to high temperatures can be related to three factors: elimination of pentosans, primarily source of nutrients; formation of furfural and cross-linking with lignin, affecting the mechanism of identification; and the formation of toxic products that can act as fungicides.

Fig. 2 presents the resistance classification due to the weight loss after the exposure of the untreated and thermomechanically treated (densified) OSB samples to the brown-rot (G.trabeum), and white-rot (T. versicolor) fungi.

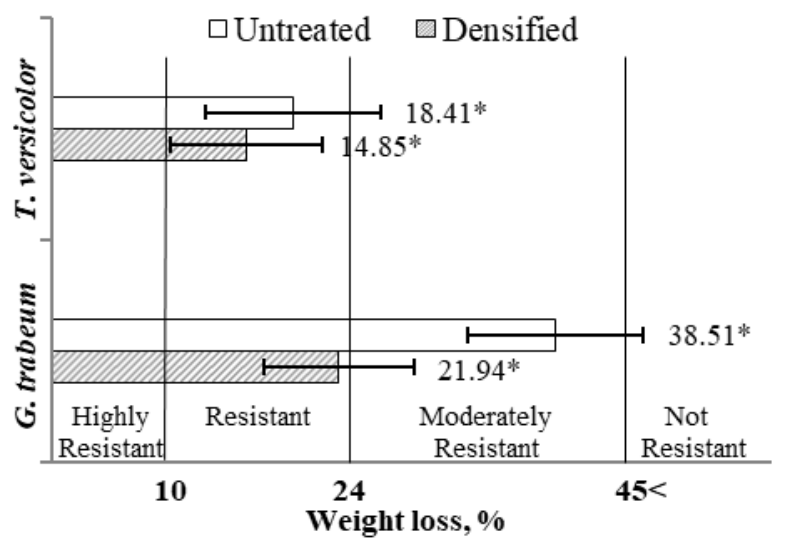

Fig. 2. Resistance class of OSB due to weight loss (\%) caused by T. versicolor and G. trabeum fungi (Note: * Significant difference at $=0.05$ levelby "ANOVA")

As for the classification of resistance to the attack of microorganisms proposed by ASTM D2007 [9], after the accelerated laboratory tests of decay, the untreated OSB panel was classified as moderately resistant to the attack of G.trabeum, and resistant to the attack of T. versicolor.

Several authors [15-17] classified the OSB panel as moderately resistant to the attack of G.trabeum, and resistant to the attack of $T$. versicolor, coinciding with the results presented in this study.Del Menezzi et al. [15] found that OSB subjected a thermal post-treatment had lower weight loss than untreated material.

Mendes et al. [18] classified the OSB panel as resistant to the attack of G.trabeum, and highly resistant to the attack of $T$. versicolor. This result can be justified by the fact that the author has made an OSB panel using $6 \%$ of adhesive, a higher value, since according toIwakiri et al. [19], the amount of phenol-formaldehyde resin used in the manufacture of OSB panels ranges from $3.0 \%$ to $6.0 \%$. Although Okino [16] has found that the increase in the adhesive percentage results in a significant reduction of weight loss,Del Menezzi et al. [20] states that the increase of the adhesive percentage is not a cost-effective procedure.

The thermo-mechanically treated OSB was classified as resistant to the attack of G.trabeum, and resistant to the 
attack of $T$. versicolor. The proposed thermo-mechanical treatment improved the decay resistance against the two evaluated fungiat $5 \%$ level, and changing the resistance class for the attack of G.trabeum, from moderately resistant to resistant,but it was not enough to change the resistance class for the attack $T$. versicolor, where the OSB remained resistant.

These results coincide with a study by Homan et al. [21], who states that the thermal treatment improve the resistance of wood to the attack of rotting fungi, and although Calonego et al. [22] affirms that the thermal treatment reduces the mechanical properties of wood as consequence of the weight loss when exposed to high temperatures, the application of pressure compensates this loss, by making the material denser and giving it a better mechanical resistance [23].

Besides, Okino et al. [24] evaluated the effect of resin content applied in OSB manufacturing and found that the application of chemical treatment increased the resistance class of the OSB from resistant to highly resistant. However, the same authors verified that the chemical treatment provoked an increase of the wood permeability, behavior that Schaffer [27] claims to affect the dimensional stability of composites, especially when used in more severe environmental humidity conditions. Therefore, although the thermo-mechanical treatment presented lower results than chemical treatment, the application of this treatment reduces higroscopicity of wood [26], which results in greater dimensional stability [4] and use possibilities.

Fig. 3 presents the visual aspects of the untreated and thermo-mechanically treated (densified) OSB samples after the exposure to decay fungi.

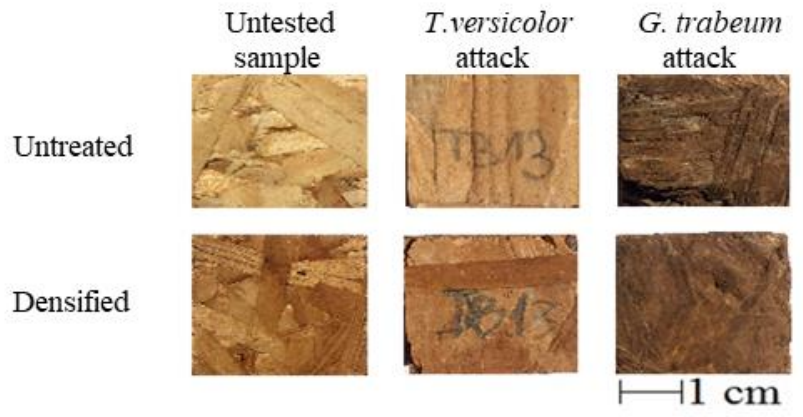

Fig. 3. Visualaspects of untreated and thermo-mechanically treated OSB samples after brown $(G$. trabeum) and white (T. versicolor) rotting

It is possible to notice that besides the objective of the thermo-mechanically treatment was to increase the OSB resistance to decay fungi, the treatment application also changed the coloration of the surface samples, leaving them with a brown color appearance. This behavior is a consequence of slow pyrolysis (when wood is heated up to $200{ }^{\circ} \mathrm{C}$ ), which causes chemical reactions that result in the softening and decrease of the hemicellulose content, alteration of the natural structure, and weight loss of lignin [27].

According to Moura \& Brito [28], the wood color is an important criterion of quality, because its description facilitates the classification and valuation of the final products of wood. However, the timber market does not consider the darkening of wood as a defect, since tropical wood has a higher economic value, and furniture industry itself applies the process of thermal rectification aiming to change the color of wood from reforestation, getting them closer to the highest market value woods [29]. The same behavior was found by Okino et al. [30] when applied thermal post-treatment on laboratory manufactured OSB panels.

For the untreated and thermo-mechanically treated OSB samples after exposure to T. versicolor attack, it is possible to notice that in both treatments the samples's surface became lighter or whitish, same result obtained by [7], who states that this behavior is a consequence of the white-rot fungi mechanism of degradation, whom attack the surface of microfibrils, provoking a progressive erosion of the wood polymers.

In contrast to the attack of white-rot fungi, the untreated and thermo-mechanically treated OSB presented a tendency to surface darkening after the attack of G.trabeum, behavior that was more evident in the untreated samples, since according to Martinez et al. [11], brown-rot fungi causes degradation of cellulose and hemicellulose, which results in a brown colored matter, composed basically of oxidized lignin.

\section{CONCLUSION}

The thermo-mechanical treatment applied of $190{ }^{\circ} \mathrm{C}$ and $1.5 \mathrm{MPa}$ was efficient to reduce the weight loss of OSB samples exposed to the attack of G.trabeum (Brownrot) and T. versicolor (White-rot) fungi. The weight loss of untreated and thermo-mechanically OSB samples presented a significant difference by the ANOVA test, and the treatment improved the resistance class to the attack of G.trabeum, from moderately resistant to resistant. However, besides the higher resistance presented to the attack of $T$. versicolor, the treatment was not enough to improve the resistance class, thus remaining resistant.There was also an increase in the weight loss by type of fungus, behavior that was already expected, since the evaluated OSB was made with Pinus sp. wood, and gymnosperms woods are more susceptible to attack of brown-rot fungi.For the wood color, the thermomechanically treatment allowed a lower variation in the OSB samples color after the attack of the rotting fungi, mainly in relation to G.trabeum which left the untreated OSB sample with a darkened coloration.

\section{Acknowlegdments}

This work was supported by Conselho Nacional de DesenvolvimentoCientífico e Tecnológico (CNPq) which led to this paper. The authors also acknowledge Fernando N. Gouveia and Marcelo F. da Silveira for their support in the facilities of the Forest Product Laboratory of the Brazilian Forest Service (LPF/SFB).

\section{REFERENCES}

1. Hill, C.A.S. Wood Modification Chemical, Thermal and Other Processes. John Wiley \& Sons, Ltd., 2006, Belgium. 
2. Currier, R.A. Compression of Douglas-fir Plywood in Various Hot-pressing Cycles Forest Research Laboratory, Information Circular 17 1962: pp. 1-37.

3. Haygreen, J.G.,Daniels, D.H. The Simultaneous Drying and Densification of Sapwood Wood and Fiber Science 1 (1) 1969: pp. $1-16$

4. Del Menezzi, C.H.S., Tomaselli, I., Okino, E.Y.A., Teixeira, D.E., Santana, M.A.E. Thermal Modification of Consolidated Oriented Strandboards: Effects on Dimensional Stability, Mechanical Properties, Chemical Composition and Surface Color Holz als Roh-und Werkstoff 67 2009: pp. 383-396. https://doi.org/10.1007/s00107-009-0332-2

5. Weiland, J.J., Guyonnet, R. Study of Chemical Modifications and Fungi Degradation of Thermally Modified Wood Using DRIFT Spectroscopy Holz als Rohund Werkstoff 61 2003: pp. 216-220. https://doi.org/10.1007/s00107-003-0364-y

6. Brazolin, S., Tomazello-Filho, M., Amaral, R.D.A.M., Oliveira-Neto, M.A. Association Between Decay Fungi and Subterranean Térmites in the Wood Biodeterioration Process of Tipuanatipu (Benth.) O. Kuntzetrees of São Paulo City, SP Scientia Forestalis 38 (86) 2010: pp. 215-224.

7. Oliveira, A.M.F., Lelis, A.T., Lepage, E.S. Agentes Destruidores da Madeira Manual de preservação de Madeiras (IPT) 1 1986: pp. 99-278.

8. Santos, P.C. Termodensificação de Painéis comerciais de OSB. [Monograph]. Brasília: Universidade de Brasília, 2016.

9. American Society for Testing and Materials - astm. ASTM D 2007: Standard Test Method of Accelerated Laboratory Test of Natural Decay Resistance of Woods. 2005, USA.

10. Bravery, A.F., Lea, R.G. Assessing the Fungus Resistance of Wood Based Composites In:IUFRO Symposium on the Protection of Wood-based Composites 1987: pp. 67-86.

11. Martinez, A.T., Speranza, M., Ruiz-Dueñaz, F.J., Ferreira, P., Camarero, S. Biodegradation of Lignocellulosics: Microbial, Chemical and Enzymatic Aspects of the Fungal Attack of Lignin International Microbiology 8 (3) 2005: pp. $195-204$.

12. Dutton, M.V., Evans, C.S., Atkey, P.T., Wood, D.A. Oxalateproduction by Basidiomycetes, Including White-rot Species Coriolus versicolor and Phanerochaete chrysosporium Applied Microbiology and Biotechnology 39 1993: pp. $5-10$. https://doi.org/10.1007/BF00166839

13. Goodell, B., Jellison, J., $\quad$ Liu, J., Daniel, G., Paszczynski, A., Fekete, F. Low Molecular Weight Chelator and Phenolic Compounds Isolated From Wood Decay Fungi and Their Role in the Fungal Biodegradation of Wood Journal of Biotechnology 53 1997: pp. 133-162. https://doi.org/10.1016/S0168-1656(97)01681-7

14. Eaton, R.A., Hale, M.D.C. Wood: Decay, Pests and Protection. Chapman e Hall, Londres, 1993.

15. Del Menezzi, C.H.S, Souza, R.Q., Thompson, R.M., Teixeira, D.E., Okino, E.Y.A., Costa, A.F. Properties After Weathering and Decay Resistance of a Thermally Modified Wood Structural Board International Biodeterioration and Biodegradation 62 2008: pp. 448-454. http://dx.doi.org/10.1016/j.ibiod.2007.11.010

16. Okino, E.Y.A. Biodegradação de Chapas de Partículas Orientadas de Pinus, Eucalipto e Cipreste Expostas a Quatro Fungos Apodrecedores Scientia Forestalis 74 2007: pp. $67-74$.
17. Choi, B.Y. Using of Fungicides or Combinations of Fungicides to Provide Mold and Decay Fungal Protection to OSB. [Thesis]. Vancouver: University of B. Columbia, 2008.

Mendes, R.F., Bortoletto, J.G., Garlet, A., Almeida, N.F., Surdi, P.G. Resistência ao Ataque de Fungos Apodrecedores em Painéis OSB Termicamente Tratados CERNE 19 2013: pp. 551-557.

http://dx.doi.org/10.1590/S0104-77602013000400004

18. Iwakiri, S., Mendes, L.M., Saldanha, L.K. Produção de Chapas de Partículas orientadas "OSB" de E. grandis com Diferentes Teores de Resina, Parafina e Composição em Camadas Ciência Florestal 13 (1) 2003: pp. 89-94. http://dx.doi.org/10.5902/198050981726

19. Del Menezzi, C.H.S., Tomaselli, I., Souza, M.R. Avaliação Não-destrutiva de Painéis OSB Modificados Termicamente: Parte 1 - Efeito do Tratamento Térmico Sobre a Velocidade de Propagação de Ondas de Tensão Scientia Forestalis 76 2007: pp. $67-75$.

20. Homan, W., Tjerdsma, B., Beckers, E., Jorissen, A. Structural and Other Properties of Modified Wood In:SHR Timber research 2000: pp. 1-8.

21. Calonego, F.W., Severo, E.T.D., Ballarin, A.W. Physical and Mechanical Properties of Thermally Modified Wood From E. grandis European Journal of Wood and Wood Products 70 (4) 2012: pp. $453-460$. https://doi.org/10.1007/s00107-011-0568-5

22. Bekhta, P., Niemz, P. Effect of High Temperature on the Change in Color, Dimensional Stability and Mechanical Properties of Spruce Wood Holzforschung 57 (5) 2003: pp. 539-546.

23. Okino, E.Y.A., Alves, M.V.S, Teixeira, D.E., Souza, M.R., Santana, M.A.E., Del Menezzi, C.H.S. Ensaio Acelerado de Laboratório de Chapas OSB de Seringueira Submetidas ao Ataque de Fungos Apodrecedores Ciência Florestal 19 2009: pp. 99-107.

24. Bufalino, L., Mendes, L.M., Tonoli, G.H.D., Scatolino, M.V., Silva, J.R.M., Mori, F.A. Relation of Transverse Air Permeability with Physical Properties in Different Compositions of Sugarcane Bagasse Particleboards Material Research 16 2013: pp. 150-157. http://dx.doi.org/10.1590/S1516-14392012005000164

25. Rowell, R.M., Banks, W.B. Water Repellency and Dimensional Stability of Wood US Department of Agriculture, Forest Service, Forest Products Laboratory General Technical Report FPL 50 1985: pp. 1-24. https://doi.org/10.2737/FPL-GTR-50

26. Schaffer, E.L. Effect of Pyrolytic Temperatures on the Longitudinal Strength of Dry Douglas Fir Journal of Testing and Evaluation 1 (4) 1973: pp. 319-329. https://doi.org/10.1520/JTE10025J

27. Moura, L.F., Brito, J.O. Efeito da Termorretificação Sobre as Propriedades Colorimétricas das Madeiras de E. grandis e P.caribaea var. hondurensis Scientia Forestalis 39 (89) 2011: pp. 69-76.

28. Zanuncio, A.J.V., $\quad$ Farias, E.S., $\quad$ Silveira, T.A. Termorretificação e Colorimetria da Madeira de E.grandis Floresta e Ambiente 21 2004: pp. 85-90. http://dx.doi.org/10.4322/floram.2014.005

29. Okino, E.Y.A., Teixeira, D.E., Del Menezzi, C.H.S. Postthermal Treatment of Oriented Strand Boards (OSB) Made from Cypress (Cupressus glauca L.) Maderas Ciencia y Tecnologia 9 2007: pp. 199-210. http://dx.doi.org/10.4067/S0718-221X2007000300001 